Pacific Journal of Mathematics

TOPOLOGIES FOR LAPLACE TRANSFORM SPACES 


\title{
TOPOLOGIES FOR LAPLACE TRANSFORM SPACES
}

\author{
DONALD E. Myers
}

\begin{abstract}
In this paper four topologies are compared:
(i) an $L_{2}$-type topology on the space of functions having bilateral transforms,

(ii) an $L_{1}$ and (iii) an $L_{2}$-type topology on the space of transforms, and

(iv) finally that of one form of convergence of compact subsets for the space of analytic functions. It is shown that sequential convergence in (i) implies (iii) and (iv) and (ii) implies (i) and (iv) and hence (iii).
\end{abstract}

In an earlier paper [2]; the author used equivalence classes of analytic functions to construct an imbedding space for Schwartz Distributions. The mechanism for constructing the mapping was the bilateral Laplace Transform, in this way the traditional approach to operational calculus was preserved. In that paper a topology was imposed on the imbedding space from the space of analytic functions. We now obtain some additional results about the possible topologies defined on the space of analytic functions.

Theorem 1. Let $F_{j}(t), j=0,1,2, \cdots,-\infty<t<\infty$ be real valued functions such that for each $j$

$$
d_{1}\left(F_{\jmath}\right)=\left[\int_{0}^{\infty}\left|e^{-\sigma_{1} t} F_{\jmath}(t)\right|^{2} d t\right]^{1 / 2}<\infty
$$

and

$$
d_{2}\left(F_{\jmath}\right)=\left[-\int_{0}^{-\infty}\left|e^{-\sigma_{2} t} F_{j}(t)\right|^{2} d t\right]^{1 / 2}<\infty
$$

where $-\infty<\sigma_{1}<\sigma_{2}<\infty$. If

$$
d\left(F_{j}-F_{0}\right)=d_{1}\left(F_{j}-F_{0}\right)+d_{2}\left(F_{j}-F_{0}\right) \rightarrow 0
$$

as $j \rightarrow \infty$ then

(i) $f_{\jmath}(z) \rightarrow f_{0}(z)$ uniformly on compact subsets of $\sigma_{1}<R(z)<\sigma_{2}$ where $f_{j}(z)=\int_{-\infty}^{\infty} e^{-z t} F_{j}(t) d t$

(ii) $\left\|f_{j}-f_{0}\right\|_{x} \rightarrow 0$

where

Received April 24, 1964. This research was partially supported by NSF Contract Grant NSF GP-1951. 


$$
\left\|f_{j}\right\|_{x}=\left[\int_{-\infty}^{\infty}\left|f_{j}(x+i y)\right|^{2} d y\right]^{1 / 2}
$$

for each

$$
\sigma_{1}<x<\sigma_{2} .
$$

Proof. From [3], pp 245, $d_{1}<\infty, d_{2}<\infty$ implies the existence of $f_{j}(z)$ with the integral defining $f_{j}(z)$ converging absolutely for $\sigma_{1}<R(z)<\sigma_{2}$. Rewrite this integral as

$$
\begin{aligned}
f_{j}(z)= & \int_{-\infty}^{0} e^{-t\left(z-\sigma_{2}\right)} e^{-\sigma_{2} t} F_{j}(t) d t \\
& +\int_{0}^{\infty} e^{-t\left(z-\sigma_{1}\right)} e^{-t \sigma_{1}} F_{j}(t) d t .
\end{aligned}
$$

By the Cauchy-Schwarz Inequality

$$
\begin{aligned}
\left|f_{j}(z)\right| \leqq & {\left[\frac{1}{2\left[\sigma_{2}-R(z)\right]} \int_{-\infty}^{0}\left|e^{-\sigma_{2} t} F_{j}(t)\right|^{2} d t\right]^{1 / 2} } \\
& +\left[\frac{1}{2\left[R(z)-\sigma_{1}\right]} \int_{0}^{\infty}\left|e^{-\sigma_{1} t} F_{j}(t)\right|^{2} d t\right]^{122} .
\end{aligned}
$$

Let

$$
g_{K}(z)=\max _{z \in K}\left[\sqrt{\frac{1}{2\left[R(z)-\sigma_{1}\right]}}, \sqrt{\frac{1}{2\left[\sigma_{2}-R(z)\right]}}\right]
$$

for $K$ an arbitrary subset of $-\sigma_{1}<R(z)<\sigma_{2}$. Now

$$
\max _{z \in K}\left|f_{j}(z)-f_{0}(z)\right| \leqq g_{K}(z) d\left(F_{j}-F_{0}\right)
$$

and (i) is established.

To prove (ii) we use an additional consequence of the theorem from [3], pp 254, namely for each $j$

$$
\int_{-\infty}^{\infty}\left|e^{-x t} F_{j}(t)\right|^{2} d t=\int_{-\infty}^{\infty}\left|f_{j}(x+i y)\right|^{2} d t
$$

for $\sigma_{1}<x<\sigma_{2}$. Since

$$
\begin{gathered}
\int_{0}^{\infty}\left|e^{-x t} F_{j}(t)\right|^{2} d t \leqq\left[d_{1}\left(F_{j}\right)\right]^{2} \\
\int_{-\infty}^{0}\left|e^{-x t} F_{j}(t)\right|^{2} d t \leqq\left[d_{2}\left(F_{j}\right)\right]^{2}
\end{gathered}
$$

it follows that

$$
\left\|f_{j}-f_{0}\right\|_{x}^{2} \leqq\left[d_{1}\left(F_{j}-F_{0}\right)\right]^{2}+\left[d_{2}\left(F_{j}-F_{0}\right)\right]^{2} .
$$

By definition $d_{1}\left(F_{j}\right) \geqq 0, d_{2}\left(F_{j}\right) \geqq 0$, therefore $d\left(F_{j}-F_{0}\right) \rightarrow 0$ implies $d_{1}\left(F_{j}-F_{0}\right) \rightarrow 0$ and $d_{2}\left(F_{j}-F_{0}\right) \rightarrow 0$ and (ii) is proved. 
Although it is clear that $d(F)$ is a norm on the set of functions with $d<\infty$ and $\|f\|_{x}$ is a norm on a subset of the functions analytic for $\sigma_{1}<R(z)<\sigma_{2}$, the topology of uniform convergence on compact sets gives only a countably normed space or a Fréchet matric. (See [1], pg. 139.)

THEOREM 2. Let $f_{j}(z), j=0,1,2, \cdots$ be functions analytic for $\sigma_{1}<R(z)<\sigma_{2}$ such that for each $j$

$$
\int_{-\infty}^{\infty}\left|f_{j}(x+i y)\right| d y<\infty, \sigma_{1}<x<\sigma_{2}
$$

and $\lim _{|y| \rightarrow \infty} f_{j}(x+i y)=0$ uniformly on closed subintervals of $\sigma_{1}<x<\sigma_{2}$. If $\left\|f_{j}-f\right\|_{x} \rightarrow 0$ as $j \rightarrow \infty$ for each $\sigma_{1}<x<\sigma_{2}$. then

(i) $d^{\prime}\left(F_{j}-F_{0}\right) \rightarrow 0$ as $j \rightarrow \infty$ where

$$
d^{\prime}\left(F_{j}-F_{0}\right)=d_{1}^{\prime}\left(F_{j}-F_{0}\right)+d_{2}^{\prime}\left(F_{j}-F_{0}\right)
$$

and

$$
F_{j}(t)=\frac{1}{2 \pi} \int_{-\infty}^{\infty} e^{x t} e^{i t y} f_{j}(x+i y) d y,
$$

$\sigma_{1}<x<\sigma_{2}$. (The prime denotes that the metric is the same as in Theorem 1, except that $\sigma_{1}$ is replaced by $x_{1}$ and $\sigma_{2}$ by $x_{2}$ where $\sigma_{1}<x_{1}<x_{2}<\sigma_{2}$.)

(ii) $f_{1}(z) \rightarrow f_{0}(z)$ uniformly on compact subsets of $x_{1}<R(z)<x_{2}$.

Proof. From [3], pg. 265 the hypotheses of the theorem are sufficient to insure that each $f_{i}(z)$ is a bilateral transform and also the validity of the inversion formula (1).

Since $\left|f_{j}(x+i y)\right| \rightarrow 0$ as $|y| \rightarrow \infty$ each $\left|f_{j}(x+i y)\right|$ is bounded for $\sigma_{1}<x<\sigma_{2}$ if $\left|f_{j}(x+i y)\right| \leqq M_{j}(x)$ then

$$
\int_{-\infty}^{\infty}\left|f_{j}(x+i y)\right|^{2} d y \leqq M_{j}(x) \int_{-\infty}^{\infty}\left|f_{j}(x+i y)\right| d y<\infty .
$$

Consider, for $\sigma_{1}<x<x_{1}$

$$
\begin{aligned}
\int_{0}^{\infty}\left|e^{x_{1} t} F_{j}(t)\right|^{2} d t & =\frac{1}{(2 \pi)^{2}} \int_{0}^{\infty}\left|e^{-t\left(x_{1}-x\right)} \int_{-\infty}^{\infty} e^{i t y} f_{j}(x+i y) d y\right|^{2} d t \\
& \leqq \frac{1}{(2 \pi)^{2}}\left\|f_{j}\right\|_{x}^{2} \int_{0}^{\infty} e^{-2 t\left(x_{1}-x\right)} d t
\end{aligned}
$$

but $0<x_{1}-x$ so that

$$
C_{1}=\frac{1}{2 \pi} \int_{0}^{\infty} e^{-2 t\left(x_{1}-x\right)} d t<\infty
$$


and $d_{1}^{\prime}\left(F_{j}\right) \leqq C_{1}\left\|f_{j}\right\|_{x}$. Likewise

$$
\int_{-\infty}^{0}\left|e^{-x_{2} t} F_{j}(t)\right|^{2} d t \leqq \frac{1}{(2 \pi)^{2}}\left\|f_{j}\right\|_{x^{\prime}}^{2} \int_{-\infty}^{0} e^{t\left(x^{\prime}-x_{2}\right)} d t
$$

for $x_{2}<x^{\prime}<\sigma_{2}$, or

$$
d_{2}^{\prime}\left(F_{j}\right) \leqq C_{2}\left\|f_{j}\right\|_{x^{\prime}}, \quad \text { where } \quad C_{2}=\frac{1}{2 \pi} \int_{-\infty}^{0} e^{t\left(x^{\prime}-x_{2}\right)} d t .
$$

If $\left\|f_{j}-f_{0}\right\|_{x} \rightarrow 0$ as $j \rightarrow \infty$ for all $\sigma_{1}<x<\sigma_{2}$ then

$$
\begin{gathered}
d^{\prime}\left(F_{j}-F_{0}\right)=d_{1}^{\prime}\left(F_{j}-F_{0}\right)+d_{2}^{\prime}\left(F_{j}-F_{0}\right) \\
\leqq C_{1}\left\|f_{j}-f_{0}\right\|_{x}+C_{2}\left\|f_{j}-f_{0}\right\|_{x^{\prime}}
\end{gathered}
$$

or $d^{\prime}\left(F_{j}-F_{0}\right) \rightarrow 0$.

Part (ii) follows by applying Theorem 1 to part (i).

In a subsequent paper the author expects to extend these to multidimensional Laplace Transforms and to Laplace Transforms on Locally Compact Abelian Groups.

\section{REFERENCES}

1. W. Thron, Introduction to the Theory of Functions of a Complex Variable, John Wiley, New York, 1953.

2. D. E. Myers, An imbedding space for Schwartz distributions, Pacific J. Math. 11 (1961), 1467-1477.

3. D. V. Widder, The Laplace Transform, Princeton, 1946.

UNIVERSITY OF ARIZONA 


\section{PACIFIC JOURNAL OF MATHEMATICS}

\section{EDITORS}

\author{
H. Samelson \\ Stanford University \\ Stanford, California \\ R. M. Blumenthal \\ University of Washington \\ Seattle, Washington 98105
}

\author{
J. Dugundu \\ University of Southern California \\ Los Angeles, California 90007 \\ *Richard Arens \\ University of California \\ Los Angeles, California 90024
}

\section{ASSOCIATE EDITORS}
E. F. BeCKENBACH
B. H. NeUMANN
F. WOLF
K. YosidA

\section{SUPPORTING INSTITUTIONS}

\author{
UNIVERSITY OF BRITISH COLUMBIA \\ CALIFORNIA INSTITUTE OF TECHNOLOGY \\ UNIVERSITY OF CALIFORNIA \\ MONTANA STATE UNIVERSITY \\ UNIVERSITY OF NEVADA \\ NEW MEXICO STATE UNIVERSITY \\ OREGON STATE UNIVERSITY \\ UNIVERSITY OF OREGON \\ OSAKA UNIVERSITY \\ UNIVERSITY OF SOUTHERN CALIFORNIA
}

\author{
STANFORD UNIVERSITY \\ UNIVERSITY OF TOKYO \\ UNIVERSITY OF UTAH \\ WASHINGTON STATE UNIVERSITY \\ UNIVERSITY OF WASHINGTON \\ * * * * \\ AMERICAN MATHEMATICAL SOCIETY \\ CALIFORNIA RESEARCH CORPORATION \\ SPACE TECHNOLOGY LABORATORIES \\ NAVAL ORDNANCE TEST STATION
}

Mathematical papers intended for publication in the Pacific Journal of Mathematics should by typewritten (double spaced). The first paragraph or two must be capable of being used separately as a synopsis of the entire paper. It should not contain references to the bibliography. No separate author's resumé is required. Manuscripts may be sent to any one of the four editors. All other communications to the editors should be addressed to the managing editor, Richard Arens, at the University of California, Los Angeles, California 90024.

50 reprints per author of each article are furnished free of charge; additional copies may be obtained at cost in multiples of 50 .

The Pacific Journal of Mathematics is published quarterly, in March, June, September, and December. Effective with Volume 13 the price per volume (4 numbers) is $\$ 18.00$; single issues, $\$ 5.00$. Special price for current issues to individual faculty members of supporting institutions and to individual members of the American Mathematical Society: $\$ 8.00$ per volume; single issues $\$ 2.50$. Back numbers are available.

Subscriptions, orders for back numbers, and changes of address should be sent to Pacific Journal of Mathematics, 103 Highland Boulevard, Berkeley 8, California.

Printed at Kokusai Bunken Insatsusha (International Academic Printing Co., Ltd.), No. 6, 2-chome, Fujimi-cho, Chiyoda-ku, Tokyo, Japan.

PUBLISHED BY PACIFIC JOURNAL OF MATHEMATICS, A NON-PROFIT CORPORATION

The Supporting Institutions listed above contribute to the cost of publication of this Journal, but they are not owners or publishers and have no responsibility for its content or policies.

* Basil Gordon, Acting Managing Editor until February 1, 1966. 


\section{Pacific Journal of Mathematics}

\section{Vol. 15, No. $3 \quad$ November, 1965}

David R. Arterburn and Robert James Whitley, Projections in the space of

bounded linear operators .................................

Robert McCallum Blumenthal, Joram Lindenstrauss and Robert Ralph Phelps,

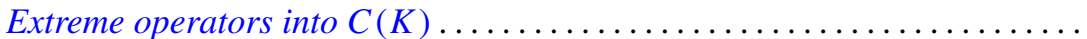

L. Carlitz, A note on multiple exponential sums ................... 757

Joseph A. Cima, A nonnormal Blaschke-quotient .................... 767

Paul Civin and Bertram Yood, Lie and Jordan structures in Banach algebras . . . 775

Luther Elic Claborn, Dedekind domains: Overrings and semi-prime

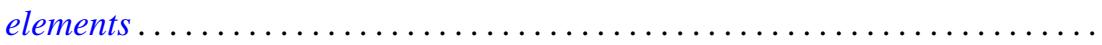

799

Luther Elic Claborn, Note generalizing a result of Samuel's .............. 805

George Bernard Dantzig, E. Eisenberg and Richard Warren Cottle, Symmetric

dual nonlinear programs ................................... 809

Philip J. Davis, Simple quadratures in the complex plane ............... 813

Edward Richard Fadell, On a coincidence theorem of F. B. Fuller ............ 825

Delbert Ray Fulkerson and Oliver Gross, Incidence matrices and interval

graphs ........................................ 835

Larry Charles Grove, Tensor products over $H^{*}$-algebras ..................

Deborah Tepper Haimo, $L^{2}$ expansions in terms of generalized heat polynomials

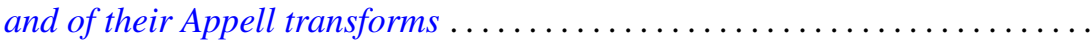

I. Martin (Irving) Isaacs and Donald Steven Passman, A chardcterization of groups in terms of the degrees of their characters ..........

Donald Gordon James, Integral invariants for vectors over local fields........ 905

Fred Krakowski, A remark on the lemma of Gauss ................... 917

Marvin David Marcus and H. Minc, A subdeterminant inequality ........... 921

Kevin Mor McCrimmon, Norms and noncommutative Jordan algebras ........ 925

Donald Earl Myers, Topologies for Laplace transform spaces ............... 957

Olav Njstad, On some classes of nearly open sets .................... 961

Milton Philip Olson, A characterization of conditional probability ........... 971

Barbara Osofsky, A counter-example to a lemma of Skornjakov .............. 985

Sidney Charles Port, Ratio limit theorems for Markov chains ............... 989

George A. Reid, A generalisation of $W^{*}$-algebras ...................... 1019

Robert Wells Ritchie, Classes of recursive functions based on Ackermann's

function ........................................... 1027

Thomas Lawrence Sherman, Properties of solutions of $n$th order linear

differential equations ........................................ 1045

Ernst Snapper, Inflation and deflation for all dimensions . .............. 1061

Kondagunta Sundaresan, On the strict and uniform convexity of certain Banach

spaces............................................. 1083

Frank J. Wagner, Maximal convex filters in a locally convex space .......... 1087

Joseph Albert Wolf, Translation-invariant function algebras on compact 